\title{
Analysis of Implementation of Cooperatives Governance and the Level of Health of Baitul Maal wat Tamwil (BMT)
}

\author{
Dita Anggraini ${ }^{1}$, Evony Silvino Violita ${ }^{1 *}$ \\ ${ }^{1}$ Faculty of Economics and Business, Universitas Indonesia, Depok 16424, Indonesia \\ *evony.silvino@gmail.com
}

\begin{abstract}
This study aims to analyze the implementation of cooperatives governance and the level of health of Baitul Maal wat Tamwil. The study uses qualitative methods alongside a case study approach in BMT Bersama Kita Berkah for the year 2014-2015. Scoring the results of the cooperatives governance index indicates that the percentage of transparency implementation in BMT BKB amounted to 88.87\%; accountability amounted to $75 \%$; responsibility amounted to $66.67 \%$; independence amounted to $94.44 \%$; and fairness amounted to $70.83 \%$. The rating of the cooperative's health under the Regulation of Supervision Deputy Ministry KUKM No. 07/Per/Dep.6/IV/2016 shows a healthy enough predicate for the years 2014 and 2015. However, there is a decrease in assessment scores from 76.36 in 2014 to 72.86 in 2015, owing to the quality of productive assets, management, efficiency, liquidity, and compliance with Islamic principles.
\end{abstract}

Keywords: Cooperatives Governance; Baitul Maal Wat Tamwil; Level of Health; Qualitative.

\section{INTRODUCTION}

Beginning in the 1980s, Baitul Maal wat Tamwil (BMT) has been inseparable from financial difficulty. Around $10 \%$ of BMT in Yogyakarta experienced this difficult, tarnishing BMT institution owing to considerable losses $^{1}$. The fate of the funds of a thousand Baitul Maal wat Tamwil customers in Perdana Surya Utama (BMT PSU) - worth about USD 17.2 billion - became opaquer after BMT PSU collapsed. The BMT Association of Indonesia (Absindo) was initially prepared to compensate customers, but is now beginning to give up².

Meanwhile, findings showed that Sharia cooperatives, including BMT, have not complied with the law, with unclear accountability practices and procedures. ${ }^{3}$ In another study, it has been stated that the factors undermining the credibility and reliability of BMT include bad accounting systems, mismanagement, fraud, and non-performing loans. ${ }^{4}$ In fact, few Sharia cooperatives and BMTs in Indonesia have effective accounting systems that can report on financial statements and accounting records correctly. There is an absence of regular reporting to stakeholders, with apparent impunity. In order to improve the performance of cooperatives, protect stakeholders, improve compliance with laws and regulations, and implement cooperative governance alongside Sharia principles and acceptable ethical values for financial institutions that manage public funds, cooperatives must correctly carry out activities related to savings and loan business and Islamic finance. ${ }^{5}$

The term 'good corporate governance' is not entirely accurate for BMTs with cooperative membership and legal entities, because in contrast to corporations, BMTs are run by members and not based on shared ownership, and voting rights are determined by the majority shareholders. While the corporation has now switched from a shareholder model to a stakeholder model, the system of governance has become more holistic, including interactions between the internal management mechanism of an organization, such as the Annual General Meeting of shareholders, the board of commissioners, board of directors, and management by an external mechanism such as stakeholder, market, regulatory board, and reputational agent. ${ }^{6}$

\section{LITERATURE REVIEW}

Good Corporate Governance comprises a system used to direct and control the activities of companies. ${ }^{7}$ The implementation of good corporate governance by companies in Indonesia is therefore vital for development and sustainable economic stability. ${ }^{8}$

The governance system itself consists of a union between (1) governance structure, (2) governance mechanisms and (3) governance principles. The governance system interacts with the internal and external environment in order to achieve the goals set. The structure comprises a framework within the organization that arranges the way in which various principles of governance can be divided, operated, and controlled. Meanwhile, the mechanism operates as a rule, procedure, and clear relationship between decision-making parties and supervisors of decision-making processes. This mechanism has a control function within the governance system. The mechanism of management discipline, for example, can be seen as a market mechanism for exercising control through the capital market mechanism, product market mechanism, and the mechanism of the labor market. ${ }^{9}$ 


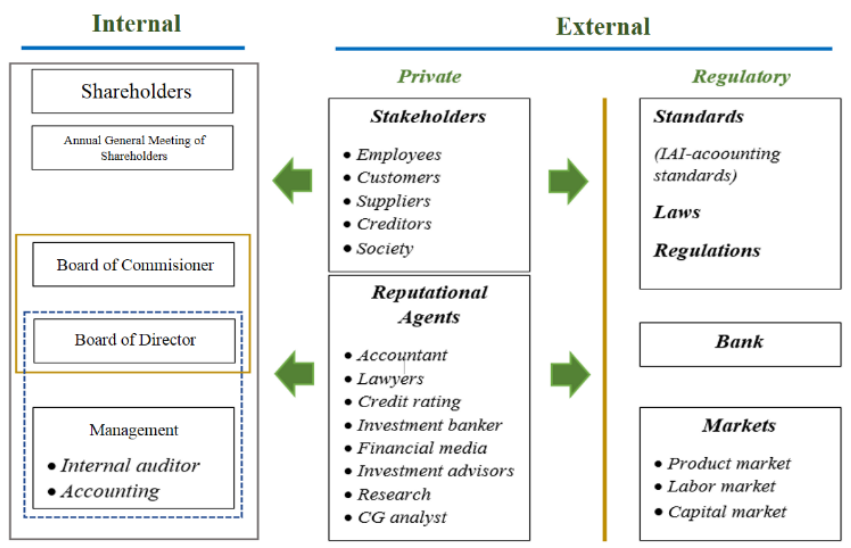

Fig.1. Corporate Governance Mechanism ${ }^{6,10}$

Figure 1 outlines the corporate governance mechanism involving various stakeholders. Stakeholders are divided into two major groups - internal stakeholders and external stakeholders. Internal stakeholders are stakeholders that are directly involved in decision-making and reside within the company's organizational structure. External stakeholders operate outside of the organization and are not directly involved in decision-making. External stakeholders can be divided into two groups - private and regulatory. This private group is composed of stakeholders and reputational agents, whereby reputational agents have a role in lowering the level of asymmetric information and overseeing the actions of the organization's management. Reputational opinions regarding these agents affect the company's reputation in the eyes of stakeholders.

Good Corporate Governance in Islamic Financial Institutions has certain differences with GCG in conventional financial institutions. The presence of additional risk in the financial system owing to Sharia and Sharia transaction limits require special supervision of the Sharia Supervisory Board. Below is a table illustrating the difference in GCG between Conventional and Islamic Corporate Governance:

Table.1. Differences between Conventional and Islamic GCG Corporate Governance ${ }^{11}$

\begin{tabular}{|c|c|c|c|}
\hline Aspects & Shareholder model & Stakeholders model & Islamic model \\
\hline Philosophy & Rationalism & Rationalism & Faith, belief, sharia, moral \\
\hline Right and interest & Protects the shareholders right & $\begin{array}{l}\text { Assure community right and the } \\
\text { relation with the company }\end{array}$ & $\begin{array}{l}\text { Protects all of stakeholders right } \\
\text { based on sharia principles }\end{array}$ \\
\hline Goals & Shareholder’s profit & Stakeholder’s welfare & Maqashid syariah \\
\hline Manager's role & Domination of managers & $\begin{array}{l}\text { Controlling shareholder’s } \\
\text { domination }\end{array}$ & Khalifah concept and discussion \\
\hline $\begin{array}{l}\text { Management } \\
\text { board }\end{array}$ & $\begin{array}{l}\text { One-tier board, no special } \\
\text { ethics committee }\end{array}$ & $\begin{array}{l}\text { Two-tier board, no special ethics } \\
\text { committee }\end{array}$ & $\begin{array}{l}\text { Sharia board and other } \\
\text { institutions responsible to the } \\
\text { issues }\end{array}$ \\
\hline Business & Unlimited business & Unlimited business & Only sharia-compliant business \\
\hline
\end{tabular}

Baitul Maal wat Tamwil comprises a combination of the two institutions, both with respective functions. Baitul Maal comes from the Arabic 'bait', which means home, and 'al maal' which means treasure. 'Bait at tamwil' is also derived from Arabic, meaning wealth management institutions and development through managing the economy. ${ }^{12}$ Good cooperative governance is hereafter referred to as the governance of KSPPS/USPPS. In this case, BMT applies principles of transparency, accountability, responsibility, independency, and fairness. Guidelines for the implementation of good cooperative governance aim to a) improve performance by protecting interests and maintaining the confidence of members and society through managing savings and loans and Islamic financing, b) improve compliance with the rules of law, the principle of cooperation and the Islamic principles and values of public ethics within a financial institution. ${ }^{5}$

The level of health of BMT is measured through a performance assessment. This measurement is defined in the Regulation Supervision Deputy Ministry of Cooperatives and Small and Medium Enterprises of the Republic of Indonesia Number 7 / Per / Dep.6 / IV / 2016 on Guidelines for the Health Assessment KSPPS and USPPS Cooperative. The scope of performance measurement includes several aspects: (1) capital, (2) the quality of productive assets, (3) management, 4) efficiency, 5) liquidity, 6) independence and growth, 7) the identity of cooperatives, and 8) Sharia principles.

\section{RESEARCH METHOD}

This study used a combination of qualitative and quantitative methods. Data was collected in the form of qualitative data (open-ended data) and quantitative data (close-ended data). The qualitative data was obtained from in-depth interviews, observation, supporting documents, and secondary sources such as books, journals, and 
internet sources. The quantitative data was obtained from financial reports documenting the object of research. This research was conducted at the Main Office of BMT Bersama Kita Berkah, Jalan Raya No. Pedati 109 Bidaracina, Jatinegara, East Jakarta 13330. The BMT notarial deed has been recorded in the Ministry of Cooperatives and SMEs. In addition, research was also carried out in the Ministry of Cooperatives and SMEs located in Jalan HR Rasuna Said Kav 3-4 Karet Kuningan Setiabudi, South Jakarta.

\section{RESULTS AND DISCUSSION}

This study performs comparisons among AAOIFI, IFSB, and the standard of Ministry of Cooperatives and SMEs. Regulations on corporate governance in KSPPS / USPPS Cooperative or BMT have not been issued, and as such, this research aims to provide recommendations by illustrating comparisons of several existing standards. Below is an example of a comparison of governance standards in Islamic Financial Institutions applied in Baitul Maal wat Tamwil.

Table.2. Comparison among AOIFI Governance Standards, IFSB and the Ministry of Cooperatives and SMEs ${ }^{13,14,5}$

\begin{tabular}{|c|c|c|c|}
\hline Aspects & AAOIFI & IFSB & Kementrian KUKM \\
\hline $\begin{array}{l}\text { Islamic governance } \\
\text { definition }\end{array}$ & Indefinable & Definable & Definable \\
\hline $\begin{array}{l}\text { Independency, } \\
\text { competence, } \\
\text { responsibility of Sharia } \\
\text { board }\end{array}$ & Definable & Definable & Definable \\
\hline $\begin{array}{l}\text { Sharia review and sharia } \\
\text { audit }\end{array}$ & Definable & Definable & Definable \\
\hline Risk management & Indefinable & Indefinable & Definable \\
\hline Internal sharia review & Definable & Indefinable & Definable \\
\hline CSR Reporting & Definable & Indefinable & Definable \\
\hline Standard scope & $\begin{array}{l}\text { SSB : appointment, } \\
\text { composition, and report, sharia } \\
\text { review, internal sharia review, } \\
\text { Audit \& Governance Committee } \\
\text { (AGC) for IFIs, independence } \\
\text { of SSB }\end{array}$ & $\begin{array}{l}\text { General approach to sharia } \\
\text { governance system, } \\
\text { competence, independence, } \\
\text { confidentiality, consistency }\end{array}$ & $\begin{array}{l}\text { Cooperatives governance } \\
\text { principles, Standard operating } \\
\text { management, Health } \\
\text { Measurement of KSPPS / } \\
\text { USPPS }\end{array}$ \\
\hline
\end{tabular}

Based on this data, the Completion of the Minister of State KUKM No. 35.2/PER/M.KUKM/X/2007 on the Standard Guidelines for Management Operations KSPPS/USPPS Cooperative ${ }^{15}$ is the most practical approach for BMT in implementing good cooperative governance. By using this approach, the result of the assessment in the form of the cooperative governance scoring index in BMT BKB presents $76.67 \%$. We can see the detail scoring in Figure 2 below:

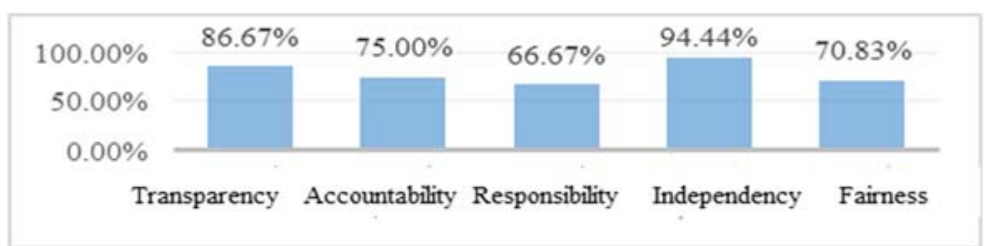

Fig.2. Details of Cooperative Governance Scoring Index in BMT Bersama Kita Berkah

\section{Transparency}

The openness of BMT in the decision-making process and material, as well as relevant information about BMT, illustrates a high level of transparency. Capital information, the quality of productive assets such as bad receivables, BMPP (Limit Provision Funding), and a financing ceiling are all presented in the Annual Meeting (RAT). The legal status of BMT can be ascertained through the information in the nameplate mounted on the front office of BMT BKB. Efficiency and liquidity information is disclosed in the Report of Daily Cash Flows. Regarding transparency in terms of independence and growth, SHU reports and distributes information related to this annually. Lastly, transparency regarding compliance with aspects of Sharia principles is met through a statement that the Sharia Supervisory Board has no family relationship by marriage with the board or manager. All of these aspects scored $86.67 \%$ for transparency.

\section{Accountability}

An accountable BMT has clear policies and rules, and mechanisms of action that are outlined in the Standard Operations Management (SOM) and Standard Operating Procedures (SOP), as well as work instructions. Any existing human resources within the BMT have clear functions, duties, responsibilities, and authorities which are described in the job description. BMT Bersama Kita Berkas has some SOP regarding fundraising and pricing 
policies that is guarded by the finance committee and supported by the Sharia supervisory board which includes KH. M. Cholil Nafis, Lc., Ph D a well-known expert on Sharia and also one of the certified members of DSN MUI. All of these aspects scored $75 \%$ for accountability.

\section{Responsibility}

BMT should comply with both the internal rules of BMT itself and external rules relating to valid laws. Firstly, according to officials ${ }^{16}$, BMT BKB has generated capital as the basis for SHU calculations. Secondly, management responsibility regarding the quality of earning assets has been carried out by BMT with their fundraising good ratio policy, members of storage, and deposit protection. Thirdly, in terms of responsibility and management aspects, BMT has developed a vision, mission, and work plan for both the long and short term. Fourthly, the efficiency of BMT BKB responsibility was not applied in the case of the depreciation of fixed assets. As is stated in Financial Accounting Standards No. $17^{17}$, depreciation of assets was used for more than one accounting period, for limited benefit, and used in the production process of goods/services for entities, in this case for fixed assets. Fifth, regarding responsibility in terms of liquidity, BMT BKB implements a consumer financing ceiling of no more than $30 \%$ of income per prospective customer and a productive financing ceiling of no more than $75 \%$ of collateral value. Sixth, responsibility and growth of BMT BKB's independence is embodied by the SHU escorting the forum board meetings, managers, and Sharia Supervisory Board. Seventh, the identity of cooperatives implements a responsibility in terms of membership and dissolution procedures set for BMT by the government. Eighth, regarding compliance with Islamic principles, BMT has DPS, but the amount has not met the set standards of at least two people.

\section{Independency}

Independence measures the professional management of BMT, taking into account conflicts of interest or the influence of any party that does not comply with the rules of law and ethical values. Firstly, independence of capital reflects that BMT investment capital comes from independent parties who have not interfered in the operations of BMT. On the other hand, BMT BKB has self-owned offices for daily operations. BMT BKB also has a high level of independence in aspects related to cooperative identity. Given the compliance with Islamic principles, the independence of BMT BKB shows the Sharia board that no family relationship by marriage affects the objectivity of the monitoring and decision making. However, as discussed regarding the principle of responsibility, the proportion of Sharia board jurisdiction is not yet fit to current standards.

\section{Fairness}

The principle of fairness is viewed as fulfilling the rights of members and stakeholders by legislation or contractual agreements that are applied fairly. Firstly, BMT BKB capital ratios are in a good enough criterions. Secondly, in terms of fairness aspects around the quality of earning assets, BKB BMT still has not made allowances for bad receivables and financing. Thirdly, regarding fairness in terms of management, BMT BKB implements deliberate mechanisms in case of conflicts of interest. The fourth principle of fairness relates to efficiency. The fifth principle of fairness relates to liquid returns on financing in BMT BKB that can be done in several forms, such as deductions on salaries, payment by partners to BMT, or billing performed by account officers. The sixth principle of fairness encompasses self-reliance and growth - BMT BKB SHU equitably distributes the appropriate amount of funds embedded as their own capital in the BMT, aligning with the value of participating members. Seventh, the principles of fairness incorporate the identity of the cooperative and are realized through any member who receives equal treatment, rather than being based on the scale of deposits or financing. Finally, for the principle of fairness that encapsulates compliance with Islamic principles, BMT BKB has included a mandatory component of any disbursement of zakat in customer financing, as a form of BMT efforts to balance business activities and the collection of maal (social funds such as zakat, infaq, sadaqah).

The rating of the BMT Bersama Kita Berkah refers to the Regulation Supervision Deputy Ministry of Cooperatives and SMEs of the Republic of Indonesia No. 07/Per/Dep.6/IV/2016. Table 3 is the health ratings of BMT Bersama Kita Berkah in the year 2014-2015. Referring to Table 3, BMT BKB has a known performance at a healthy-enough level. Overall, five out of eight aspects caused a decline in the level of the BMT BKB health score among scores pertaining to asset quality, management, efficiency, liquidity, and compliance with Islamic principles. The percentage of the application of cooperative governance of $76.67 \%$ is not known to have an immediate relationship with the assessment results regarding the performance level of BMT BKB, which were fairly healthy (about 72-76, healthy enough). However, based on the final scores of Table 3's results, the BMT BKB assessment rating is 76.36 in 2014 and 72.86 in 2015. This demonstrates that the value aligns with the results of the index scoring cooperative governance. The following comprise a few examples of connections found in this study:

The performance aspects of asset quality assessment results indicate a relatively poor health level compared to other aspects. Criteria ratios relating to financing, receivable accounts and nonperforming loans decline from the current criteria to substandard, while the criteria for risky financing portfolio ratios decreased risk. BMT accountability in related policy added to the quality of earning assets, and SOM/SOP are also still not 
implemented, so the effect on BMT responsibility on compliance with the Regulation of the Minister of State KUKM No. 35.2/PER/M.KUKM/X/2007 ${ }^{15}$ regarding the lack of functional clarity and active mechanisms is related to the quality of earning assets, contributing to high losses from bad receivables and financing. BMT has not made an allowance for bad receivables and financing, meaning that in the calculation reports, the results of operations overly disclose SHU to ascertain the amount of funds received by BMT, compared with large receivables and financing to continue BMT's outstanding outage. This could worsen the ratio of the value of asset quality, which is one indicator of the health of BMT.

Table.3. Assessment of BMT Bersama Kita Berkah Performance Year 2014-2015

\begin{tabular}{|c|c|c|c|c|c|c|c|}
\hline No & Aspects measured & Ratio 2014 & Ratio 2015 & Score 2014 & Score 2015 & Status 2014 & Status 2015 \\
\hline \multirow[t]{3}{*}{1.} & Capital & & & & & & \\
\hline & $\begin{array}{l}\text { a. Ratio of self-capital to total } \\
\text { capital }\end{array}$ & $7.26 \%$ & $18.70 \%$ & 1.25 & 3.75 & Unhealthy & $\begin{array}{l}\text { Healthy } \\
\text { enough }\end{array}$ \\
\hline & b. Capital Adequacy Ratio & $11.94 \%$ & $16.30 \%$ & 5.00 & 5.00 & Healthy & Healthy \\
\hline \multirow[t]{4}{*}{2.} & Productive Assets Quality & & & & & & \\
\hline & $\begin{array}{l}\text { a. Ratio of bad financing and } \\
\text { credit to total financing and } \\
\text { credit }\end{array}$ & $4.70 \%$ & $35.52 \%$ & 10.00 & 2.50 & Good & Not so good \\
\hline & $\begin{array}{l}\text { b. Ratio of risky financing } \\
\text { portfolio }\end{array}$ & $0.80 \%$ & $26.88 \%$ & 5.00 & 2.50 & Risky & $\begin{array}{l}\text { Risky } \\
\text { enough }\end{array}$ \\
\hline & $\begin{array}{l}\text { c. Ratio of allowance of } \\
\text { productive assets }\end{array}$ & $31.5 \%$ & $40.18 \%$ & 0.16 & 2.46 & Bad & Doubtful \\
\hline \multirow[t]{6}{*}{3.} & Management & & & & & & \\
\hline & a. General management & $92 \%$ & $92 \%$ & 2.75 & 2.75 & Good & Good \\
\hline & b. Institutional management & $100 \%$ & $100 \%$ & 3.00 & 3.00 & Good & Good \\
\hline & c. Capital management & $80 \%$ & $80 \%$ & 2.40 & 2.40 & Good & Good \\
\hline & d. Assets managemnt & $80 \%$ & $70 \%$ & 2.40 & 2.10 & Good & $\begin{array}{l}\text { Good } \\
\text { enough }\end{array}$ \\
\hline & e. Liquidity management & $80 \%$ & $80 \%$ & 2.40 & 2.40 & Good & Good \\
\hline \multirow[t]{4}{*}{4.} & Efficiency & & & & & & \\
\hline & $\begin{array}{l}\text { a. Ratio of operational to gross } \\
\text { profit }\end{array}$ & $53.51 \%$ & $47.26 \%$ & 4.00 & 4.00 & Efficient & Efficient \\
\hline & $\begin{array}{l}\text { b. Ratio of fiixed assets to total } \\
\text { assets }\end{array}$ & $24.87 \%$ & $25.64 \%$ & 4.00 & 3.00 & Good & $\begin{array}{l}\text { Good } \\
\text { enough }\end{array}$ \\
\hline & c. Ratio of staff efficieny & 148.82 & 194.56 & 2.00 & 2.00 & Good & Good \\
\hline \multirow[t]{3}{*}{5.} & Liquidity & & & & & & \\
\hline & a. Cash Ratio & $18.90 \%$ & $25.99 \%$ & 5.00 & 10.00 & $\begin{array}{l}\text { Not so } \\
\text { liquid }\end{array}$ & Liquid \\
\hline & $\begin{array}{l}\text { b. Ratio of financing to fund } \\
\text { received }\end{array}$ & $40.48 \%$ & $36.86 \%$ & 1.25 & 1.25 & Not liquid & Not liquid \\
\hline \multirow[t]{4}{*}{6.} & Independence and Growth & & & & & & \\
\hline & a. Return on Assets & $1.24 \%$ & $1.20 \%$ & 0.75 & 0.75 & Low & Low \\
\hline & $\begin{array}{l}\text { b. Return on Equity (self- } \\
\text { capital) }\end{array}$ & $510.45 \%$ & $386.07 \%$ & 3.00 & $3 . .00$ & High & High \\
\hline & $\begin{array}{l}\text { c. Return of operational } \\
\text { autonomy }\end{array}$ & $114.22 \%$ & $114.33 \%$ & 2.00 & 2.00 & Lack & Lack \\
\hline \multirow[t]{3}{*}{7.} & Identity of Cooperatives & & & & & & \\
\hline & a. Ratio of gross profit & $100.00 \%$ & $100.00 \%$ & 5.00 & 5.00 & Useful & Useful \\
\hline & $\begin{array}{l}\text { b. Ratio of Economic Member } \\
\text { Participation }\end{array}$ & $182.20 \%$ & $82.33 \%$ & 5.00 & 5.00 & High & High \\
\hline \multirow[t]{2}{*}{8.} & $\begin{array}{l}\text { Sharia Compliance } \\
\text { a. General management }\end{array}$ & $100.00 \%$ & $80 \%$ & 10 & 8.00 & Complied & $\begin{array}{c}\text { Complied } \\
\text { Enough }\end{array}$ \\
\hline & & & TOTAL & 76.36 & 72.86 & $\begin{array}{l}\text { HEALTHY } \\
\text { ENOUGH }\end{array}$ & $\begin{array}{l}\text { HEALTHY } \\
\text { ENOUGH }\end{array}$ \\
\hline
\end{tabular}

Another example is in compliance with Islamic principles. Predicate BKB BMT 2015 on the compliance aspects of Sharia principles adhere to the acquisition score of 8 out of a maximum score of 10. BMT accountability aspects in compliance with Islamic principles have shown competence and an astute educational background of the Sharia board which supports them in carrying out its duties in terms of the oversight of contract-related transactions. This certainly contributes to the assessment of compliance with Sharia principles of BMT BKB.

\section{CONCLUSION}

Based on this research, here are some things that can be inferred include: 
1) BMT Bersama Kita Berkah has already applied the five principles of cooperative governance, including transparency, accountability, responsibility, independence, and fairness of $76.67 \%$ in the management of BMT. Judging this based on five principles, independence gave a percentage of $94.44 \%$, which has been applied properly on each element assessed. The principles of responsibility reached $66.67 \%$.

2) Based on the results of the rating on capital, asset quality, management, efficiency, liquidity, independence and growth, cooperative identity, and compliance with Islamic principles, BMT Bersama Kita Berkah attained a 'healthy enough' predicate for the years 2014 and 2015. However, the assessment score decreases from 76.36 in 2014 to 72.86 in 2015.

3) It is not known whether the percentage of the application of cooperative governance of $76.67 \%$ has a direct relationship with the results of assessment of the level of performance/health of BMT BKB. However, by looking at a few examples and the fact that the percentage of implementation of the cooperative governance index (76.67\%) aligns with the health assessment scores of BMT BKB (76.36 in 2014; 72.86 in 2015), further research is needed to determine the effect of the application of cooperative governance on the level of health/ performance of BMT.

\section{REFERENCES}

[1] Republika. BMT Bermasalah di DIY Capai 10 Persen, Retrieved on 4 December 2016, http://www.republika.co.id/berita/syariah/keuangan/11/08/19/lq5gx4-bmt-bermasalah-di-diy-capai-10-persen (2011).

[2] Radar Malang. Asosisasi BMT angkat tangan, Jawa Timur, Indonesia, (2015).

[3] D. Siswantoro. Regulatory Compliance and Experiences of Islamic Cooperatives in Competitive Business in Indonesia. International Journal of Excellence in Islamic Banking and Finance, 3(1)(2013).

[4] D. Siswantoro, N. Sri. Accounting practices in Islamic cooperatives in Indonesia: Is a good accounting record needed? (A question for sustanability). International Conference on Sustainable Innovation (ICOSI), (2012) 145-155.

[5] Kementrian Koperasi dan UKM. Peraturan Deputi Pengawasan Kementrian Koperasi dan UKM Nomor: 07/Per/Dep.6/IV/2016 tentang Pedoman Penilaian Kesehatan KSPPS dan USPPS Koperasi, (2016).

[6] A. Cadbury. Corporate governance: a framework for implementation. The World Bank Group, Washington DC, (2000).

[7] OECD. OECD Principles of Corporate Governance, https://www.oecd.org/daf/ca/Corporate-Governance-Principles-ENG.pdf (2015).

[8] Komite Nasional Kebijakan Governance. Pedoman umum good corporate governance Indonesia. KNKG, Jakarta (2006).

[9] A. Syakhroza. Corporate governance: sejarah dan perkembangan, teori, model, dan sistem governance serta aplikasinya pada perusahaan BUMN. Universitas Indonesia, Depok, (2005).

[10] Kim and Nofsinger. Corporate Governance, Prentice Hall, United States, (2004).

[11] M. A. S. Nugroho. Urgensi penerapan Islamic corporate governance di Baitul Maal Wat Tamwil (BMT). Jurnal Kajian Bisnis, 23(1)(2015) 64-70.

[12] E. Amalia. Perspektif good corporate governance dalam implementasi sistem manajemen BMT di Indonesia. Kumpulan Hasil Riset Terbaik, Forum Riset Keuangan Syariah OJK, (2015) 365.

[13] AAOIFI. Governance standard for Islamic financial institutions, Bahrain, (2009) 4-97.

[14] Islamic Financial Services Board. Guiding principles on sharia governance systems for institutions offering Islamic financial services. IFSB, Kuala Lumpur, (2009).

[15] Kementrian Koperasi dan UKM. Peraturan Menteri Negara Koperasi dan UKM RI Nomor 35.2/PER/M.KUKM/X/2007 tentang Pedoman Standar Operasional Manajemen KJKS dan UJKS Koperasi, (2007).

[16] S. Aslamia. Wawancara penerapan tata kelola koperasi dan penilaian tingkat kesehatan BMT BKB, (2016).

[17] Ikatan Akuntan Indonesia. Pernyataan standar akuntansi keuangan, Ikatan Akuntan Indonesia, Jakarta, (1994). 